\title{
Black Africans' Religious and Cultural Assimilation to, or Appropriation of, Catholicism in Italy, $1470-1520^{*}$
}

\author{
KATE LOWE \\ Queen Mary, University of London
}

Dans cet article, j'examine trois exemples d'africains sub-sahariens présents dans l'Italie de la Renaissance et qui ont assimilé avec succès les fondamentaux du catholicisme. On considère qu'il était impossible pour les noirs africains en Europe de se réinventer une nouvelle identité sans être préparés à apprendre comment mener une vie de catholique pieux. Toutefois, ce niveau d'assimilation était contesté régulièrement par les Européens 'blancs'. On en examine trois exemples : le premier concerne les préjugés courants qui empêchaient qu'un couple d'esclaves noirs donne leur enfant le nom d'un saint catholique. Un deuxième exemple consiste en l'introduction d'un donateur noir dans un retable du $X V^{e}$ siècle. Le troisième exemple analyse le contenu religieux du testament d'une femme d'Afrique noire.

$I^{2}$ $\mathrm{n}$ this article, I shall focus on a trio of examples of sub-Saharan or black Africans in Italy, whether enslaved or freed, who can be seen to have assimilated successfully to some basic tenets of Catholicism, and to have undergone a conversion of behaviour and mores as well as a compulsory religious "conversion." Current scholarship emphasizes that the old model of conversion-of, say, Christianity being actively forced onto passive and subordinate peoples - is no longer satisfactory, and instead prefers to frame the issue around concepts of cultural interaction or cultural transmission, and selective appropriation of the host religion. ${ }^{1}$ According to the new model, what used to be seen as assimilation might rather be interpreted as, or indeed possibly be, appropriation. If seen in this light and relabelled, real or perceived appropriation of the religious and cultural practices of the host country by slaves could appear threatening to the established social order, something to be feared instead of something to be desired. There are multiple ways in which appropriation/assimilation can be gauged, and I am differentiating here between the very large number of acts of appropriation/assimilation that were or may have been involuntary, and the very small number we know of at the moment where it is clear that the Africans themselves had made an active choice ${ }^{2}$ to participate in Catholic acts (when there was no compulsion to do so). Another current scholarly 
preoccupation, engaging with the literature on identity formation, focuses attention on 'the converts' transition from one moral community to another, and analyses the converts' transformation into properly-constituted Catholic subjects, capable of filling normative kinship and institutional roles." 3 Filling these roles by integrating to a high degree could equally be perceived as an aggressive, rather than a conformist, move. Both these approaches have a great deal to offer in terms of aiding a discussion of the present topic, but neither takes into account the fact of slavery, which necessitates separate study. If those undergoing (or choosing) conversion are or were slaves, the possibility of choice or agency is much more limited, and the parameters of the argument have to be redrawn. Furthermore, although the subject of conversion-however perceived and understood-is presently much in vogue, scholars working on the Italian Renaissance have in the main focused upon conversion from Judaism to Christianity, or from Islam to Christianity, or even, most recently, from Christianity to Islam, ${ }^{4}$ but no one has yet investigated the conversion of sub-Saharan Africans from the set of beliefs labelled "animism" to Christianity. 5 This was a transformation enacted mainly in southern European countries (although it would also have taken place, to a far lesser extent, in northern European countries), but the whole process must also have been influenced by and dependent upon the customs and practices of the host country or political entity, in this case, the city states of Renaissance Italy, as Catholicism was both permeable and localized.

The majority of sub-Saharan Africans enslaved on the west coast of Africa after 1440, and brought to Europe, were "animist,"6 as Islam had only penetrated to a few places below the Sahara at this date, such as the ancient kingdom of Ghana, which, however, did not extend to the coast, although the kingdom of Mali, which also included some Muslims, did. Black Africans brought to Europe via North Africa, on the other hand, were more likely to have been Muslim or to have been converted to Islam while in North Africa, and the experience of a (possibly second) European "conversion" for them would have been different. Of the West African peoples caught up in the European slave trade, the Wolof of Senegambia were the most Islamicized, but only those at the top of the social scale, according to the European travellers and traders Alvise da Mosto and Valentim Fernandes, who both claimed that people not in this group were animist rather than Muslim. ${ }^{7}$ Alvise da Mosto also discussed the religious beliefs of the people living around the River Gambra, another area from which Africans were enslaved. Once again, he maintained that the majority of the population were animist, and claimed that those who were Muslim were those who "frequented" other countries. ${ }^{8}$ If this distinction between animist and Muslim might 
appear irrelevant, it was certainly believed to be an important one in Renaissance Europe, where Muslim slaves were the least trusted and most feared of all the slave groups or categories. In Portugal, for instance, the law sometimes differentiated between Muslim slaves and non-Muslim slaves, in favour of the latter. ${ }^{9}$ No work has yet been done linking the origin of slaves to the arrival of slave ships in Portugal and the onward export of slaves to Italy. But the great majority of sub-Saharan Africans in Florence and Tuscany during the late fifteenth and early sixteenth centuries can safely be assumed to have come from West Africa via Portugal, whereas those in Venice may have come from the eastern part of the continent and have arrived via North Africa.

To a greater or lesser extent, black Africans in Southern Europe in the period 1470-1520 were unable to invent new identities for themselves if they were not prepared to conform and to learn how to lead the lives of good Catholics. Just as the rewards for this behaviour could be great, the penalties and privations suffered by those who resisted or even actively fought religious assimilation (or who, according to the new model, chose not to appropriate aspects of Christianity) must have been enormous. On the other hand, the Catholic church's willingness or hesitation in welcoming black Africans into the fold is a telling marker of whether the church genuinely believed that their souls were equal to the souls of European Catholics. Africans in Renaissance Italy also had to contend with ordinary prejudice from ordinary people (as was the case right across Europe) which made the task of religious and cultural assimilation to, or appropriation of, Catholicism considerably harder to accomplish. A third part of this equation - over and above the responses of the Catholic church and ordinary people - was the attitude of the secular authorities, who were in charge of defining the preconditions for full membership of civil society, and who could demand not only assimilation to Catholicism but also membership in community groups as visible signs of a right to belong. ${ }^{10}$ In this scenario, therefore, conversion was a critical, but early, stage of what was to be a very long process for Africans attempting to obtain new, European identities.

Remaining altogether outside the embrace of Catholicism was clearly not an option for most black African slaves, especially if they wanted to participate in everyday Catholic life, and benefit from the advantages of membership of the Catholic community. Fernando, a black slave in the Canary Islands who came to the attention of the Inquisition because his owner was a so-called New Christian, testified in 1519 that he wanted to be allowed to become a Christian, even though there were "no Christians in [his] land [of origin]," because he now lived in a Christian land, "and if I die [as a non-Christian] they will not bury me, but throw me into 
a field." 11 In Fernando's case, the pull factor was fear of what would happen to his physical remains after his death if he did not convert to Catholicism. But for many others, it must just have made sense to assimilate to the dominant religious "systems" in operation in their "new" countries, and learning how to navigate these systems comfortably was the equivalent of learning how to use European legal systems to their advantage. Debra Blumenthal in her work on sub-Saharan African women in Valencia in the late fifteenth century has shown how quickly these women had learnt to have recourse to the law for help in their struggles with their owners. ${ }^{12}$

I recently co-edited a volume on Black Africans in Renaissance Europe, and in my chapter I examined how the stereotyping of black Africans was used in Renaissance Europe - verbally, textually, and visually — as an analytical category that excluded sub-Saharan Africans from much of mainstream European life and culture during that period. ${ }^{13}$ The black slaves whose history forms the basis of my first example can be used to illuminate the difficulties black Africans in Europe faced even when they attempted cultural and religious assimilation (and in this case I believe that it was assimilation and not appropriation). On 10 December, 1470, a baby girl was left at the orphanage of the Ospedale degli Innocenti (literally "the Hospital of the Innocents") in Florence. The record taker who recorded her arrival wrote these notes on the case: the baby was brought by Agniesa d'Arezo, who was accompanied by a slave of Bengni Strozzi's called Ghaleotto. Ghaleotto said that the child was his, and that her mother was Lixabetta, a black (nera) slave who also belonged to Bengni Strozzi. Ghaleotto wanted the child to have the name Lucia, and she was baptized with that name the same day. Then the record taker added, obviously wanting to record what he considered to be a surprising fact: "The said Ghaleotto was himself black (nero)." 14 It must have been very surprising that the child had two black slave parents. While 34 of the first 100 babies deposited had been born to slave mothers, none was known to have been born to a slave couple. ${ }^{15}$ So this is an extremely early example of two black Africans having a child in Italy after the Portuguese slave raids and expeditions along the coast of West Africa began in the 1440s, and enslaved Africans from these coasts started appearing across much of Southern Europe (the first documented black African slaves shipped from Lisbon to Tuscany under the auspices of the Cambini bank arrived in Florence in 1461). ${ }^{16}$ This may even be the first black child born to two black parents in Florence in the Renaissance, because it was very unusual at this date for there to be more than one black slave in a household, and very unusual for there to be a black African male domestic slave; in fact, also rather unusual for there to be a male domestic slave or servant before the end of the fifteenth century. ${ }^{17}$ As slaves were not usually permitted to marry in Northern 
or Central Italy, ${ }^{18}$ having sex while living under the same roof may have been the closest these two could come to being a "couple" in Renaissance Florence.

There are several other striking or unusual aspects to this story. More than 60 percent of children mentioned in the Florentine ricordanze (diaries and journals) dated between 1350 and 1530 studied by Christiane Klapisch-Zuber had a second name (while only 15 percent had a third name), and the choice of these second names was overwhelmingly related to a patron saint. ${ }^{19}$ At the Innocenti, on the other hand, virtually all the "abandoned" children were given two names, and the second name often served to "identify" the child. Lucia's second "name," chosen presumably by the record keeper at the Innocenti, was Negra, a "descriptive" name just meaning black (there is a difference between negra and nera, with negra in terms of skin colour usually signifying a sub-Saharan African and nera covering a much greater range from dark to "black"). Other babies at the Innocenti were also allocated descriptive names. For example, one little girl was christened "Richa" as her father was rumoured to be a rich citizen who had apparently said that he would come to reclaim her. ${ }^{20}$ These second names of Negra and Richa are very distinctive, and point to a Renaissance desire to differentiate on occasion between foundlings and those of legitimate birth by marking the child with an inalienable name. ${ }^{21}$ Second, the report makes clear that the name Lucia was the choice of the father Ghaleotto, but the reason for the choice is that the feast of St. Lucia was the nearest major female saint's day ${ }^{22}$ (it is celebrated on 13 December) to the date of the dropping off of the child. In contradistinction to their second names, which were overwhelmingly chosen for pious reasons, legitimate Catholic children in Florence were given saints' names as their first names out of a sense of piety in less than 20 percent of cases if they were male, and less than 10 percent if they were female. ${ }^{23}$ Thus the naming practices at the Innocenti ran counter to normal behaviour, and although Ghaleotto's choice of name reveals that he had assimilated culturally and religiously to such an extent that he was aware of saints' days and their significance in naming practices, he was probably unaware that Florentine first names were normally allocated from the paternal family stock of given names rather from these saints' names. In any case, black African parents baptized with Christian names did not have the option of giving their children the names of dead grandparents or other dead relatives, ${ }^{24}$ as their relatives would not have had Christian names, so their only option was to pick a new Christian name, and start a new tradition. Although babies' names were primarily chosen by fathers, ${ }^{25}$ slave fathers would not usually have been allowed to name their own children, who would instead have been named by the owners of the slaves. ${ }^{26}$ Third, it was much more unusual for a man to bring in a child than 
a woman, and highly unusual, as in this case, for a father to accompany his child while it was being dropped off. Of the bearers of the first 100 children left at the Innocenti after its foundation in 1445, only two were fathers, and only fourteen were unrelated men, as opposed to 37 unrelated women. ${ }^{27}$ But it should also be pointed out that black is not always straightforwardly black in the documentation, and that the terminology often needs to be interpreted. For instance, the orphanage files also record that on 19 September 1473 another baby girl was left at the Innocenti-the man described as a ghezzo, a gypsy or someone with darker than usual skin, who brought the child in said that he was called Marciotto, that he was the father, and that he "lived with Bengni Strozzi"; the child was named Maria and Domenicha. ${ }^{28}$ Finally, on 17 January $1483 / 4$ a black (nero) male baby was deposited, brought in by a woman who said nothing. But the names given the child are revealing: Salimbene Antonio Ghezzo. ${ }^{29}$

It was the custom for those leaving children at the orphanage also to leave a few pieces of cloth with the child. Most of the time these were just scraps-pezze line or pezze lane, and sometimes fascie (swaddling clothes).$^{30}$ But further evidence that Ghaleotto felt affection towards his child is offered by the fact that on 12 December, along with other pieces of cloth dropped off for Lucia, was a man's shirt ("una camicia da uomo"), a highly unusual garment to find in these lists. One can only speculate that it was Ghaleotto's, and that it might have belonged originally to Bengni.

It is heartbreaking, therefore, to find in the documentation that already on 11 December (that is, the day after Lucia had been left and a day before Ghaleotto probably returned with the shirt from his own back), this new-born baby had been put out to "work" for the orphanage. The records note that she was "lent" ("demo in prestanza") to a man called Lorenzo di Cresci. She thus became entangled in the Renaissance web of practices and conventions surrounding breastfeeding, referred to by one historian as "the market in milk". Lorenzo's wife must have been expecting a baby, and a wet nurse would have already been hired, but the baby must have been late in arriving, and baby Lucia would have been "lent" to perform the service of keeping the wet nurse's milk flowing while waiting for Lorenzo's wife's baby to arrive. This was a not uncommon occurrence, which allowed the institution to save on the cost of sending its own babies out to wet nurses. ${ }^{31}$ But in Lucia's case, it had tragic consequences, and she died just five days after being sent out from the Innocenti, on 16 December, in the house of Lorenzo di Cresci. Whether Lucia was more likely to have been sent out to serve this purpose because she was the child of slaves, or because she was black, is not known. 
Bengni di Jacopo d'Ubertino Strozzi's double appearance in this very short narrative is striking too, especially as in neither case is he named as the father (many Florentine babies left at the Innocenti were the children of middle-class males who had had sex with their female slaves or servants), ${ }^{2}$ and in both cases the baby is the child of Africans or people with dark skin. In Bengni's 1469 tax return for S. M. Novella, Leon Bianco, he is indeed recorded as the owner of two slaves: the first, a female, cost 32 fiorini and the second, a male, cost 25 fiorini. ${ }^{33}$ Although their skin colour is not specified (and it often is in the catasto, the tax return), these must be Lixabetta and Ghaleotto. The difference in price was probably related to age: Lixabetta must have been younger and stronger with more years of work in her. The two of them must have been acquired since 1457 which was the date of the previous tax return, when they are not mentioned. Bengni, who was 65 in 1469, was living alone with his two slaves, creating an uncommon household, and it is slightly strange in the circumstances that he did not allow his slaves to keep their childmany slave owners would have thought of an extra child as a valuable commodity. One possibility is that Bengni wanted to make quick money by hiring Lixabetta out as a wet nurse to someone else's baby. ${ }^{34}$ Another is that the child was deposited for "good" rather than "bad" reasons, as by being left at the Innocenti, she shed her slave status and became a free person, whereas if she had stayed in Bengni Stozzi's household, she would have shared the slave status of her parents. ${ }^{35}$ The law was complicated in relation to a child's legal status: in the case of a child born to parents of unequal status, Roman law assigned it the status of the mother, yet Florentine statutes decreed that the status of a child followed that of its father. ${ }^{36}$ In Lucia's case, of course, there was no discussion as both parents were slaves. Although Ghaleotto's behaviour provides evidence of religious and cultural assimilation on his part, the terminology and naming practices revealed by the Innocenti documents stand as witness to the levels of prejudice that sub-Saharan Africans must have encountered in Renaissance Florence. Even when they learnt and conformed to European and Christian sets of behaviour, they were still regarded and labelled as black. Cultural and religious assimilation (understanding of naming practices, participation in the custom of donating clothing to a baby to be left at the orphanage, possibly knowledge of the free legal status to be gained by depositing the baby at the orphanage) were not sufficient to guarantee acceptance, and may indeed have been perceived rather as appropriation; therefore acceptance of Africans as Catholics and Europeans in Renaissance Europe remained very contested.

My second example gives stark evidence of the kinds of misinformation and prejudice about the lives of black Africans in Renaissance Europe that still abound, 
both because of innate preconceptions and because of a lack of academic work on the subject. The example concerns cultural and religious assimilation in a visual mode. In $2004 \mathrm{I}$ came across a late fifteenth/early sixteenth-century Florentine painting of tempera and gold on panel entitled The Coronation of the Virgin, St. Jerome and St. Anthony of Padua (Fig. 1), now in the Christian Museum in Esztergom in Hungary, acquired from the collection of a certain canon Bertinelli in Rome in 1878. The painting has been variously ascribed in the past to Neri di Bicci, workshop of Neri di Bicci, workshop of Domenico Ghirlandaio, Sebastiano Mainardi, 37 and The Master of the St.-Louis Madonna, ${ }^{38}$ and is now usually ascribed a rough date of $c$. 1495. As yet there is no Renaissance documentation for this painting, but it is now considered most likely that the artist was Davide Ghirlandaio, 39 brother of the more famous Domenico, and that the painting was produced in the Ghirlandaio workshop..$^{40}$ Davide (born c. 1452) was Domenico's closest collaborator, but he remains quite a shadowy figure and it is difficult to ascertain securely not only his exact role in many dual commissions, but also independent work done by him alone. Although the most interesting (and extraordinary) aspect of this painting is the black African figure on the right-hand side at the bottom, no mention of him is made in either of the nineteenth-century inventories of the Bertinelli collection; ${ }^{41}$ very paradoxically, his black skin colour makes him so unimportant as to be "invisible."

The painting is also enigmatic in a variety of other ways. It measures 109.8 $\mathrm{x} 71.6 \mathrm{~cm}$, so although it would have been rather small for an altarpiece, it would have been too large for a private devotional panel. It was most likely to have been an altarpiece, but one appended to a column or wall of an aisle instead of being the focal point of a chapel. The painting consists of two separate and separated halves, which could almost be two distinct paintings. The upper section shows the Virgin being crowned in heaven by God the Father, Jesus, and the dove symbolizing the Holy Ghost. The subject matter of the coronation of the Virgin ${ }^{42}$ depicts the final moment of the Virgin's glorification, often associated with her assumption. The iconography of this subject is rather complicated, making it unlikely that this was a panel painted for speculative sale on the open market, when a Madonna or Pietà would have been much more likely to sell; the subject matter points towards a private or individual commission. The lower section of the painting is set on earth, with a Tuscan walled city, water and mountains in the background, and it foregrounds two kneeling saints: St. Jerome with a cardinal's hat and lion, and St. Anthony of Padua holding a flaming heart.

It had been suggested in the past that the black figure on the lower right is "the attribute of the saint kneeling above [St. Anthony of Padua], and refers to an event 
from his life related to Saracens," 43 but this is incorrect and the black figure is, in fact, the donor (Fig. 2). St. Anthony of Padua is already holding his attribute of a flaming heart, from which the African is completely separate. The reason for this kind of conflation or confusion of attribute and donor is that there has been little work on free or freed black Africans in Renaissance Italy, and it is not generally appreciated that they existed, and so it has hitherto been considered impossible for black Africans to be donors. ${ }^{44}$ Only the upper part of the man's body is represented (he is dressed in black and perhaps there is a badly darkened but originally whitish collar peeking out around his neck), and his hands are not visible (the absence of hands folded in prayer is also used to refute the donor status of the African). When the painting was cleaned in 2000-2001, it was confirmed that the painting had not been cut down, so no more of the man's body ever existed. In terms of size, the African donor is only slightly smaller than the two saints in the foreground.

Donor paintings were standard in the Italian Renaissance, but because it was quite expensive to commission a painting, it was normally only the relatively wealthy and those of a certain social status who did so. This donor painting with a black African donor therefore provides very exciting evidence of black assimilation to, or appropriation of, religious and cultural Italian Renaissance norms. Having himself depicted as a donor shows that this man has assimilated culturally and religiously to (or may have been perceived to have appropriated) Catholicism in a very specialized way. That is, he accepts the arguments in favour of the religious efficacy of commissioning and paying for a painting into which he has had inserted a likeness of himself as donor. And it is also probable that he chose the two saints depicted, either because of a link through naming (as this would be the second example, the first being Ghaleotto in Florence, perhaps Italian/Catholic naming practices were compatible with the naming practices in some parts and societies of West Africa), or out of devotion to their cult.

Two other paintings attributed to Davide Ghirlandaio contain donors of interesting and important comparability. The first is a panel of tempera and oil of St. Lucy with a half-bust portrait of the donor, the Dominican fra Tommaso Cortesi, 45 in the bottom right-hand corner, hanging in Santa Maria Novella in Florence. The donor's name is known not only on account of the inscription on the frame-DEPINGI FECIT ME THOMAS OPTIMA PROLIS CORTESIAE GENTIS SERVVS ET IPSE DEI [Thomas, the excellent offspring of the Cortesi clan and servant of God, caused me to be painted] — but also because of a seventeenth-century copy of a now lost payment record, probably dated $1494 .{ }^{46}$ Tommaso Cortesi is dressed in black friar's garb, with a white collar and white cuffs peeping out under his robes. He is 
portrayed in profile to the left, and is painted in a similar size to the female saint; he has his hands joined in prayer. In this painting, the donor cannot be confused with the saint's attributes because Lucy holds her eyes on a platter far away from Tommaso Cortesi. This single male donor is comparable to the black African in every respect except that the African's hands are not visible, and he is not praying. A second donor painting of tempera with oil glazes on panel, formerly attributed to Domenico Ghirlandaio but now reattributed to Davide, belongs to the Fitzwilliam Museum in Cambridge. Entitled Virgin and Child Enthroned between St. Ursula and St. Catherine (Fig. 3), and dated c.1480 to 1500, the donor this time is female, a nun (Fig. 4), placed as usual in the bottom right-hand corner of the painting. ${ }^{47}$ She too is portrayed in profile to the left and is only slightly smaller than the two saints and the Virgin. The panel measures $66.4 \times 41.6 \mathrm{~cm}$ and therefore is the right size for a devotional panel. In terms of attributes, St. Ursula is depicted with an arrow in her neck, and St. Catherine has a piece of her familiar wheel, but even though the wheel is very close to the nun, there is no confusion of the two. And most importantly for our purposes, the nun's hands are not visible and she is not praying, yet no one has questioned her status as the donor. By comparing the Esztergom painting with these other two donor paintings attributed to Davide Ghirlandaio, I hope to have shown conclusively that the African is not an attribute, but the donor himself.

What can be ascertained by looking closely at the detail of the as yet unidentified black African? There are two plausible explanations why the head of the African is so much more alive than the other "participants" in the painting. The first is because it is a portrait of a real person whereas the other faces are "composite" or imaginary people. As it was a portrait, the artist had to pay closer attention. But here too there are unusual aspects. The donor exhibits a great deal of realism in his face, and shows emotion (or some experience of emotion) yet he is not allotted any gestures. Nor is he assigned any markers of status, even though he is the person in the picture who needs them. The interiority of the African is in sharp contrast to the blandness of the saints, who by contrast seem to be cardboard cut-outs. This is the opposite of what is usually the case; the saints normally are the focus of attention, and the donors are emotionless and insignificant. The second reason is that the artist may have paid greater attention to the figure of the donor because it was the first time he had painted an African and he therefore painted both with unwonted spontaneity and with unusual care. From the portrait, it can be deduced that the African was probably over 35 , as his hair appears to be thinning and receding, and his neck was slightly fat, with the beginnings of a double chin. I had thought initially that, because it appeared of a higher quality to the rest of the painting, the figure of 
the African might have been added to the painting at a later date (either the painting had been produced as a speculative sale, or the painting had been initiated under one painter's regime but had been left unfinished at his death, and been re-used later by another painter). ${ }^{48}$ This does not now seem likely. ${ }^{49}$ One reason is the iconography of the coronation, a second the composition itself, and a third that the saints were probably chosen by the donor (that is, it is probable that the choice of saints had some significance - the donor had one of their names and/or had been born on their feast day, or was particularly attached to them and/or their cults). But given what is known of the working practices of Ghirlandaio and his workshop, ${ }^{50}$ it is additionally worth raising the separate but related question of whether the donor figure could have been painted (roughly simultaneously) by a different painter (but one from the same workshop) to the rest of the panel. For instance, Berenson thought that this was the case with the St. Lucy panel, where he ascribed the depiction of the saint to Benedetto Ghirlandaio and the depiction of the donor to Davide. ${ }^{51}$ This division of labour is a more distinct possibility, although at the moment a judgment would have to be made on stylistic grounds alone.

The identity of the African is unknown, but there are a few further clues to his identity. Portugal and Spain were the two European countries with the most significant black populations at this period, and black is the colour most associated with Spanish and Portuguese dress, so the donor might have been from the Iberian peninsula. For example, on 19 January $1487 / 8$ a proclamation (bando) was issued in Florence offering a reward to anyone who knew the whereabouts of a runaway black African slave from Spain called Brianda who was "dressed in black in the Spanish fashion" ("vestita di nero alla spagniuola").52 It is possible that the free or freed sub-Saharan African in the Davide Ghirlandaio painting may have been in the household of a Spanish prelate or ambassador. St. Anthony of Padua was, in fact, born in Lisbon and is much venerated in Portugal so this could be an additional pointer. But the African does not have to have come through Spain or Portugal. By the late fifteenth century, black was also the most fashionable colour for Venetian dress, for example. Marin Sanudo, when writing of the clothes of the Venetians at the end of the fifteenth century, mentioned their black stockings, and then stated: "conclusive, usano molto il negro" ("in conclusion, they use black a great deal"),53 and Paul Hills wrote that "Venetian society was one in which the absoluteness of black-its separation from all colours - was a defining issue." 54

Whoever the donor is, this painting represents a crucial moment in the "encounter" between black Africans and Renaissance Europe, when a black African, 
following Catholic Italian precedent and tradition, takes his place as a commissioner of a work of art that includes his own image and likeness.

A final example of cultural and religious assimilation is to be found in the will of a woman called Lucia "de genere ithyopia" ("of the people of sub-Saharan Africa"), drawn up in Venice in 1511.55 The word "Ethiopia" indicated not that the woman was from Ethiopia but that she was black, and it was much in use in Venice in the late fifteenth and early sixteenth century for black slaves in patrician households. However, Lucia was not a slave, although she may have been an ex-slave. The will was drawn up by Isidoro Bagnolo, the parish priest (plebano) of SS. Apostoli. Venice was unusual in allowing priests to be notaries, ${ }^{56}$ and so this example is a little less secure (in terms of it being certain that Lucia was not pressurized into making her choices) than the two others, as the person detailing the assimilation was a functionary of the Catholic church. Lucia said she lived in the house of the procurator, Nicolò Michiel (1461-1518),57 and named her husband Daniele de Rebus as her executor. Her exact status in the household is unclear; she does not appear to be a servant. ${ }^{8}$ Her will enumerates a programme of Catholic services that she wishes to be enacted on her behalf after her death (such as masses for the remission of her soul in the year following her death), details expenditure (for example, on her burial and on masses for the dead), and nominates the charitable activity of choice to which the residue of her estate should be directed, which would allow the celebration of marriages by poor, young people of legitimate issue. All these religious and cultural activities were of Lucia's own choosing. They might have been suggested to her by other people, but she was sufficiently in charge of her own destiny to make a will and to outline how she wished her money to be spent, and by these conventionally pious bequests she showed the extent of her assimilation to Renaissance Venetian values and modes of behaviour. At the same time, it is possible that the preoccupation with the state of her (and others') soul(s) might be related to her former slave status, as two earlier examples of wills by ex-slave women on Venetian Crete that exhibit the same concern have been found. 59 It is notable that Lucia instituted two types of mass. The first was a series of masses with her own soul as the intention of the mass, thus gaining remission for her soul of time in purgatory, while the second was a series of 30 masses for the dead in general, in which the intention of the mass was for the less fortunate dead in purgatory (some merit must also have been attached to her as the sponsor of these). Similarly, the fact that Lucia did not name the local organization to which she wanted the residue of her estate to go fits in with some slight further evidence of recently freed ex-slaves revealing a lack of knowledge about local charities. ${ }^{60}$ 
These three examples show in differing measure that black Africans in Italy between 1470 and 1520 - that is, very shortly after the arrival in the peninsula of the first slaves from West Africa - were capable of assimilating both culturally and religiously to Catholicism. But in each case assimilation to Catholicism was not the end of the story, because these Africans who were in the process of adopting European identities were also labelled or marked as "black," two verbally (by the use of the descriptors "Negra" and "de genere ithyopia") and one visually by his skin colour. Whether this was because their attempts at assimilation were viewed by the church, ordinary Italians, or the secular authorities as appropriation is not clear; what is clear is that their willingness to assimilate, and the consequences of their assimilation, were contested. One must conclude, therefore, that religious and cultural assimilation to Catholicism was just a first step for these black Africans towards acceptance in a white, Christian society that had not yet thought through the implications of demanding the religious conversion of enslaved Africans. Black Africans still had a great deal further to go before they would be genuinely accepted either as Catholics or as Europeans. 
80 KATE LOWE

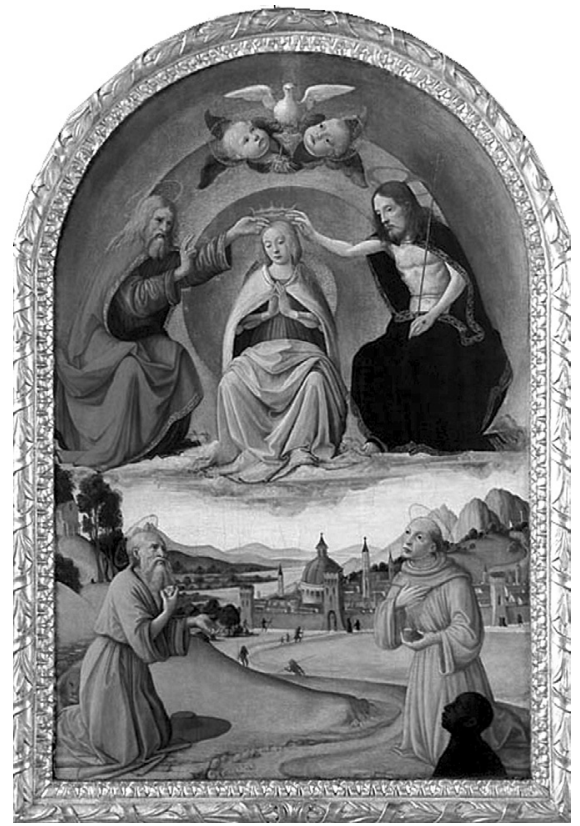

Figure 1: Davide Ghirlandaio (attr.), The Coronation of the Virgin, St. Jerome and St. Anthony of Padua, Keresztény Múzeum, Esztergom. Photograph by Attila Mudrák.

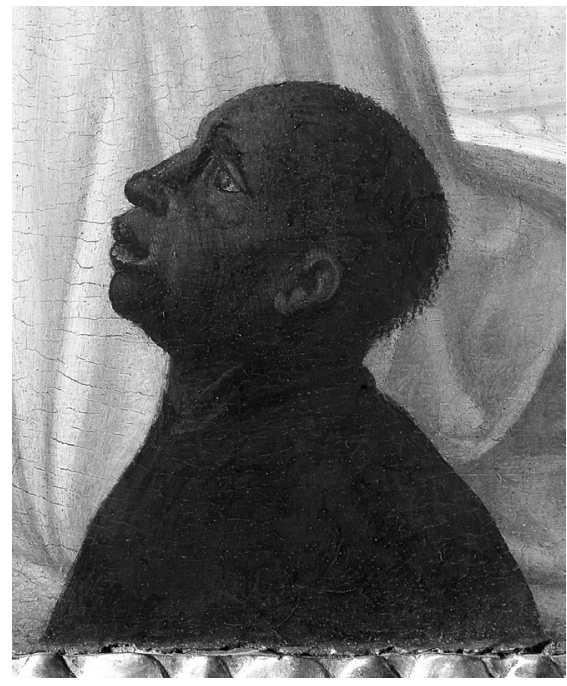

Figure 2: Detail of donor from Fig. 1. 


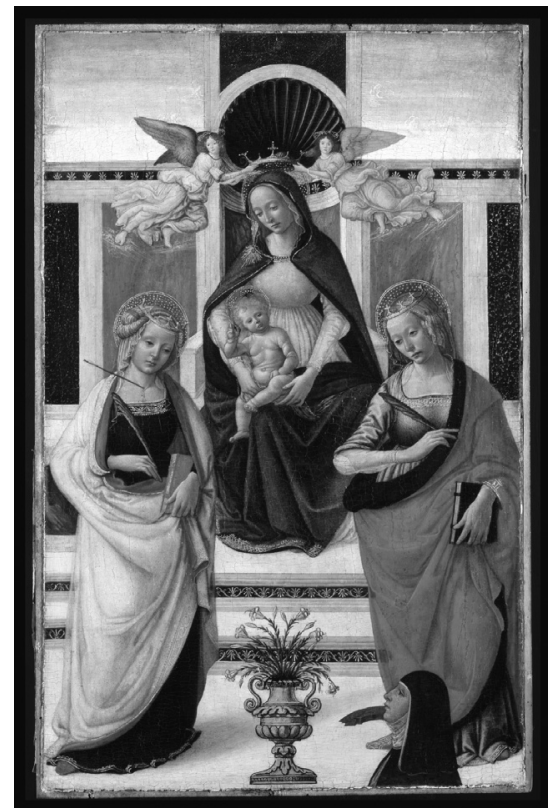

Figure 3: Davide Ghirlandaio, Virgin and Child Enthroned between St. Ursula and St. Catherine, Fitzwilliam Museum, Cambridge.

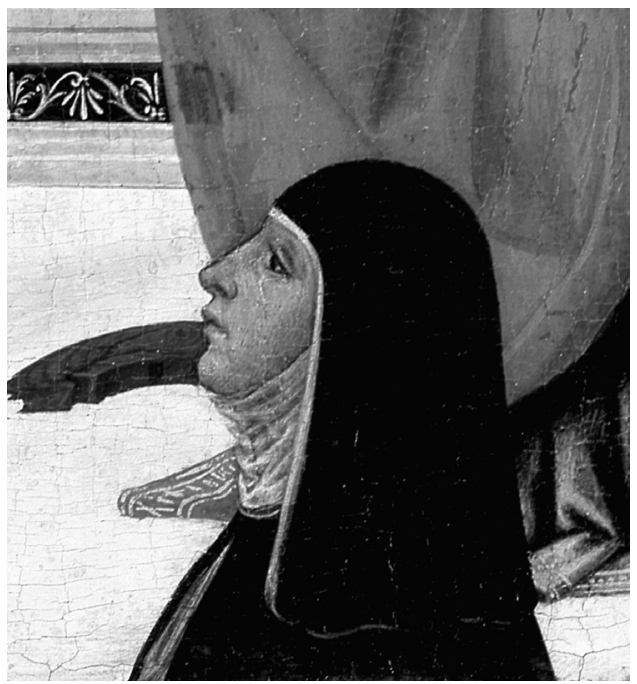

Figure 4: Detail of donor from Fig. 3. 


\section{Notes}

* I should like to thank audiences at Queen Mary, University of London, at the Palermo conference on "Schiavitù e conversioni religiose nel Mediterraneo di età medievale e moderna" run by Giovanna Fiume in May 2007, and at the Renaissance Society of America's Annual conference in Chicago in April 2008, for their very helpful comments. I regret that I was unable to prepare this article for publication in time to be included in the special issue of Quaderni storici that resulted from the Palermo conference, but I believe it has found an equally appropriate home in this special issue of Renaissance and Reformation/Renaissance et Réforme. I should like to single out for thanks Philippa Jackson, who first brought the Davide Ghirlandaio painting with the black donor to my attention, and Dora Sallay, the former curator of Italian painting at the Christian Museum, Esztergom, who was extremely generous about sharing information on the painting. I am also grateful to Dave Clarke, Amanda Lillie, Mick O’Malley, Jonathan Rolls, Dennis Romano, Lucia Sandri, David Scrase, and Christa Gardner von Teuffel for their help.

1. Kenneth Mills and Anthony Grafton, "Introduction," in Conversion: Old Worlds and New, eds. Kenneth Mills and Anthony Grafton (Rochester, NY: University of Rochester Press, 2003), pp. ix-xvii at ix-x.

2. I see this topic as a continuation of work I have done in the past on choice exercised by other groups, such as nuns. See, e.g., Kate Lowe, "Nuns and choice: artistic decisionmaking in Medicean Florence," in With and Without the Medici: Art and Patronage in Florence, 1434-1530, ed. Eckart Marchand and Alison Wright (Aldershot: Ashgate, 1998), pp. 129-53.

3. See E. Natalie Rothman, "Becoming Venetian: conversion and transformation in the seventeenth-century Mediterranean,” Mediterranean Historical Review 21:1 (2006), pp. $39-75$ at 40 and 57 .

4. There is a considerable secondary literature on these topics. See the special issue entitled "Schiavitù e conversioni religiose nel Mediterraneo di età medievale e moderna," edited by Giovanna Fiume, in Quaderni storici 126, anno XLII, n. 3 (2007).

5. But see Steven A. Epstein, Speaking of Slavery: Color, Ethnicity and Human Bondage in Italy (Ithaca, NY: Cornell University Press, 2001), and the chapter on "Blacks and Christianity," by A. C. de C. M. Saunders in his A Social History of Black Slaves and Freedmen in Portugal, 1441-1555 (Cambridge: Cambridge University Press, 1982), pp. 149-65. It might be instructive to consider parallels between the conversion of "animist" Africans and the conversion of people in pre-Christian Europe, for which see Guyda Armstrong and Ian N. Wood ed., Christianizing Peoples and Converting Individuals (Turnhout, Belgium: Brepols, 2000).

6. Precise details of the belief systems of West African slaves at this date are few and far between, and those that do exist come mainly from European sources, making their deciphering more complicated, but it is undoubtedly a great over-simplification uncritically to bracket these beliefs together, and refer to them as "animist." 
7. Tullia Gasparrini Leporace, ed., Le navigazioni atlantiche del veneziano Alvise da Mosto (Rome: ISMEO, 1966), p. 44 (for an English translation, see G. R. Crone ed., The Voyages of Cadamosto and Other Documents on West Africa in the Second Half of the Fifteenth Century [London: The Hakluyt Society, 1937], p. 31), and Théodore Monod, A. Teixeira da Mota and R. Mauny ed., Description de la côte occidentale d'Afrique (Sénégal au Cap de Monte, Archipels) par Valentim Fernandes (1506-1510) (Bissau, Publicações do Centro de Estudos da Guiné Portuguesa, 1951), pp. 6 and 8.

8. Gasparrini Leporace ed., p. 102, and Crone ed., p. 70.

9. Saunders, pp. 120-22.

10. Tamar Herzog, Defining Nations: Immigrants and Citizens in Early Modern Spain and Spanish America (New Haven and London: Yale University Press, 2003), pp. 119-21 and 128-29, discusses how immigrants could be defined in or defined out by the secular authorities, and how people could be labelled as foreigners even if they had been born and brought up in a country.

11. Jews in the Canary Islands: Being a Calendar of Jewish Cases Extracted from the Records of the Canariote Inquisition in the Collection of the Marquis of Bute, translated and edited by Lucien Wolf (originally, London: Spottiswoode, Ballantyne \& co. Ltd., 1926, reprinted Toronto: University of Toronto Press, 2001), p. 24, quoted in Jonathan Schorsch, Jews and Blacks in the Early Modern World (Cambridge: Cambridge University Press, 2004), pp. 193-94.

12. Debra Blumenthal, “La casa dels Negres': black African solidarity in late medieval Valencia," in Black Africans in Renaissance Europe, eds. T. F. Earle and K. J. P. Lowe (Cambridge: Cambridge University Press, 2005), pp. 225-46.

13. Kate Lowe, "The stereotyping of black Africans in Renaissance Europe," Black Africans in Renaissance Europe, pp. 17-47.

14. Florence, Archivio dell'ospedale dell'Innocenti (AOIF), Balie e bambini dall'anno 1466 all'anno $1472 \mathrm{G}(1466-1472)$, s. 16, no. 7 (491), fol. 339v. This record was partially transcribed by Ridolfo Livi, La schiavitù domestica nei tempi di mezzo e nei moderni (Padua, 1928), p. 240, and re-used by Charles Verlinden, L'esclavage dans l'Europe médiévale, 2 vols. (Ghent, 1955 and 1977), vol. 2, pp. 377-8.

15. Richard C. Trexler, "The foundlings of Florence, 1395-1455," History of Childhood Quarterly, 1:1 (1973), pp. 259-84 at 270. But cf. Iris Origo, "The domestic enemy: the eastern slaves in Tuscany in the fourteenth and fifteenth centuries," Speculum 30:3 (1955), p. 348.

16. Sergio Tognetti, “The trade in black African slaves in fifteenth-century Florence," Black Africans in Renaissance Europe, pp. 213-24 at 217.

17. Christiane Klapisch-Zuber, "Female celibacy and service in Florence in the fifteenth century," in Women, Family and Ritual in Renaissance Italy, ed. Christiane Klapisch-Zuber, trans. Lydia G. Cochrane (Chicago: University of Chicago Press, 1985), pp. $165-77$ at $176-77$.

18. In Sicily, there is evidence from the fourteenth century that slaves were occasionally married, and records of two black freed couples have been found (Palermo, Archivio 
di stato, Notai Defunti, Prima stanza, S. Pellegrino 2, fol. 95r, and 4, fol. 221v). Several other freed couples, or couples with one freed partner, may have included a black person. I am grateful to Henri Bresc for this information.

19. Christiane Klapisch-Zuber, “The name 'remade': the transmission of given names in Florence in the fourteenth and fifteenth centuries," in Women, Family and Ritual in Renaissance Italy, pp. 283-309 at 293.

20. Trexler, p. 271.

21. See Thomas Kuehn, Illegitimacy in Renaissance Florence (Ann Arbor: University of Michigan Press, 2002), pp. 120-21.

22. On the use of major and obscure saints' names, see Klapisch-Zuber, "The name 'remade," pp. 293-4.

23. Klapisch-Zuber, "The name 'remade'," p. 292. In the Veneto, the personal names chosen were also most likely to be from the family stock of names, repeats of the names of dead relatives. Saints' names also had their place there, with Giovanni or Giovanna most common (invoking the protection of John the Baptist), and saints' names from a family cult also popular. "Slightly less commonly invoked was the saint on whose day the child was born." See James S. Grubb, Provincial Families of the Renaissance: Private ad Public Life in the Veneto (Baltimore and London: Johns Hopkins University Press, 1996), pp. 46-47.

24. For good examples of occasions when the names of dead relatives were re-used in the Strozzi family, see Ann Crabb, The Strozzi of Florence: Widowhood and Family Solidarity in the Renaissance (Ann Arbor: University of Michigan Press, 200o), p. 32; for examples of moments when they were not, see pp. 206-207.

25. Klapisch-Zuber, “The name 'remade'," p. 288.

26. For a Portuguese example of slave parents choosing the name of their child, see Saunders, p. 90.

27. Trexler, p. 265.

28. AOIF, Balie e bambini dall'anno 1472 all'anno 1476 H (1472-1476), s. 16, no. 8 (492), fol. $88 \mathrm{v}$. This was partially transcribed by Livi, La schiavitù domestica, p. 241. Some societies in West Africa also named children according to the day of the week on which they had been born.

29. AOIF, Balie e bambini dall'anno 1482 all'anno 1485 L (1482-1485), s. 16, no. 11 (495), fol. 122v. This was partially transcribed by Livi, La schiavitù domestica, p. 242.

30. Trexler, pp. 268-69: "in 95 of the 100 cases, the child arrived with trivial pieces of cloth its only dowry"; and Philip Gavitt, Charity and Children in Renaissance Florence: the Ospedale degli Innocenti, 1410-1536 (Ann Arbor: University of Michigan Press, 1990), p. 188.

31. See Lucia Sandri, "Baliatico mercenario e abbandono dei bambini alle istituzioni assistenziali: un medesimo disagio sociale?” in Donne e lavoro nell'Italia medievale, eds. Maria Giuseppina Muzzarelli, Paola Galetti, and Bruno Andreolli (Turin: Rosenberg \& Sellier, 1991), pp. 93-103 at 97.

32. See Gavitt, p. 207. 
33. Florence, Archivio di stato, Catasto 921, fol. 85 r.

34. Kuehn, p. 111.

35. Giulia Calvi suggested to me that the Innocenti as an institution became the fictive kin of the children who were abandoned to its care. See Gavitt, pp. 143-44 and 259.

36. Origo, pp. 344 and 364 , note 113 .

37. Tibor Gerevich, "Esztergomi mükincsek," in Prímás Album (Budapest, 1928), pp. 179263 at 231. I should like to thank Vivien Papp for translating the relevant sections of Gerevich.

38. See Everett Fahy, "Some early Italian pictures in the Gambier-Parry Collection," The Burlington Magazine, 109 (1967), pp. 128-39 at 137, note 34 and Miklós Boskovits, Tuscan Painters of the Early Renaissance, translated by Eva Rácz (Budapest: Corvina, 1968), p. 41.

39. For an early Davide Ghirlandaio attribution, see Bernard Berenson, Italian Pictures of the Renaissance: A List of the Principal Artists and their Works with an Index of Places (Oxford: The Clarendon Press, 1932), p. 222. On Davide Ghirlandaio, see Jean K. Cadogan, Domenico Ghirlandaio: Artist and Artisan (New Haven and London: Yale University Press, 2000), pp. 153-60, and Ronald G. Kecks, Domenico Ghirlandaio und die Malerei der Florentiner Renaissance (Munich and Berlin: Deutscher Kunstverlag, 2000), pp. 117-22.

40. On Ghirlandaio's workshop, see Cadogan, pp. 153-71, and Kecks, pp. 115-32.

41. Written communication from Dora Sallay, Curator of Italian Painting at the Christian Museum, Esztergom, 1 November 2004.

42. Domenico Ghirlandaio and his workshop/assistants painted at least two other paintings of the coronation of the Virgin, and drew at least three drawings. The closest in style is that now at Città di Castello (see Cadogan, pp. 146 and 269-70).

43. Website of the Christian Museum in 2004 (now removed). The entry on the website in May 2008 read: "In the lower right corner the profile of a Saracen appears. It is in all likelihood the commissioner's portrait": <http://www.christianmuseum.hu/collections.php mode $=$ work $\&$ wid $=68 \&$ page $=\&$ search $=$ ghirlandaio $>$.

44. For recent work on black slaves in Italy, see Sergio Tognetti, pp. 213-24.

45. For information about Cortesi, see Stefano Orlandi, "Necrologio" di S. Maria Novella. Testo integrale dall'inizio (MCCXXXV) al MDIV corredato di note biografiche tratte da documenti coevi con presentazione del P. Innocenzo Taurisano, 2 vols. (Florence: Leo S. Olschki, 1955), vol. 1, p. 201 and vol. 2, pp. 347-48.

46. Cadogan, pp. 159 and 324.

47. W. G. Constable, Catalogue of Pictures in the Marlay Bequest, Fitzwilliam Museum, Cambridge (Cambridge: The University Press, 1927), pp. 11-12 and plate v (painting attributed to Bartolommeo di Giovanni), and Fitzwilliam Museum, Cambridge, Catalogue of Paintings, 2 vols. (Cambridge: The Fitzwilliam Museum, 1960 and 1967), vol. 2, Italian Schools, J. W. Goodison and G. H. Robertson, eds., pp. 60-1 and plate 3 (painting attributed to a follower of Domenico Ghirlandaio). In a letter of 1985 from Everett Fahy to David Scrase of the Fitzwilliam, Fahy stated that he believed that this 
painting, which he had formerly grouped with the Master of the St. Louis Madonna altarpiece, was by Davide Ghirlandaio.

48. When I was able to examine the painting in July 2006, the difference appeared less marked.

49. Dora Sallay remains convinced that the head was not a later addition.

50. See, for example, the documents about the altarpiece with three saints and four kneeling donors commissioned by Elisabetta of Rimini from Domenico Ghirlandaio, and finished after his death by Davide Ghirlandaio, in Hannelore Glasser, Artists' Contracts of the Early Renaissance, Columbia University, Ph.D., 1965 (Ann Arbor: University Microfilms Inc., 1976), pp. 197-200, 301-7. It was common practice for different elements of paintings to be assigned to different members of the workshop, with the "master" painting only the most important parts.

51. Bernard Berenson, Italian Pictures of the Renaissance, (rev. ed., London: Phaidon Press, 1957-68, 3 vols. in 7), Florentine School, 2 vols., 1, p. 73.

52. Florence, Archivio di stato, Otto di Guardia (Repubblica) 221, fol. 197r.

53. Marino Sanuto, [Cronachetta] [Venice, 1880], p. 34.

54. Paul Hills, Venetian Colour: Marble, Mosaic, Painting and Glass, 1250-1550 (New Haven and London: Yale University Press, 1999), p. 186.

55. Venice, Archivio di stato, Notarile testamenti, Atti Bagnolo, b. 1153, n. 56.

56. On this, see Giorgio Cracco, "Relinquere laicis que laicorum sunt: Un intervento di Eugenio IV contro i preti-notai di Venezia," Bolletino dell'Istituto di storia della società e dello stato veneziano 3 (1961), pp. 179-89.

57. On whom, see D. S. Chambers, "Merit and money: the procurators of St. Mark and their commissioni, 1443-1605," Journal of the Warburg and Courtauld Institutes 60 (1997), pp. 23-88 at 51 and 85, and Venice, Archivio di stato, Miscellanea codici, serie I, 20, p. 120.

58. For further information on servants' wills in Venice, see Dennis Romano, Housecraft and Statecraft: Domestic Service in Renaissance Venice, 1400-1600 (Baltimore: Johns Hopkins University Press, 1996), pp. 182-7, and for servants' wills in seventeenthcentury Tuscany, Giovanna Benadusi, "Investing the riches of the poor: servant women and their last wills," American Historical Review 109:3 (2004), pp. 805-26.

59. Sally McKee, Wills from Late Medieval Venetian Crete, 1312-1420, 3 vols. (Washington, D.C.: Dumbarton Oaks Research Library and Collection, 1998), vol. 2, pp. 533-34, no. 411 and 548-49, no. 422. These wills were discussed in Epstein, pp. 138-9.

6o. Epstein, p. 139. 